\title{
Nitric Oxide Alleviates Copper Toxicity in Germinating Seed and Seedling Growth of Lactuca sativa $L$.
}

\author{
Mostafakamal SHAMS ${ }^{1}$, Ertan YILDIRIM ${ }^{1 *}$, Guleray AGAR ${ }^{2}$, \\ Sezai ERCISLI ${ }^{1}$, Melek EKINCI ${ }^{1}$, Atilla DURSUN ${ }^{1}$, Raziye KUL ${ }^{1}$ \\ ${ }^{1}$ Ataturk University, Faculty of Agriculture, Department of Horticulture, 25240 Erzurum, Turkey; \\ mkamalsun@gmail.com; rertanyil@atauni.edu.tr(*correspondingauthor); sercisli@atauni.edu.tr; ekincim@atauni.edu.tr; \\ atilladursun@atauni.edu.tr; raziye.kul@atauni.edu.tr \\ 2Ataturk University, Faculty of Science, Department of Biology, 25240 Erzurum, Turkey; gagar@atauni.edu.tr
}

\begin{abstract}
Copper has many metabolic functions in the plants. However, it can be toxic to plants where it reaches the excess level. The aim of the present study was to evaluate the role of nitric oxide treatments on lettuce seed germination under copper stress. Thus a factorial laboratory experiment with a completely randomized design was carried out at the Ataturk University. Treatments include different doses of copper $(0,50,100,150$ and $200 \mu \mathrm{M}$ of copper sulfate) and nitric oxide $(0,50,100,150$, 200 and $300 \mu \mathrm{M}$ of sodium nitroprusside). The results of this study monitored that high concentration of copper (100, 200 and $300 \mu \mathrm{M})$ had a significant effect on the germination percentage, germination rate, mean period of ultimate germination, seed vigor index, seedling fresh weight and allometry coefficient, although the nitric oxide treatment (without copper) had not a significant effect on the seeds in comparing to the untreated ones. Copper treatment decreased the investigated parameters, but the simultaneous application of nitric oxide and copper had a positive impact. The results of this study suggested that nitric oxide treatments have been beneficial upon the seeds that treated with copper, but not upon the seeds that treated with water. In addition, the lower concentration of copper $(50 \mu \mathrm{M})$ had a positive effect on the seed vigor index.
\end{abstract}

Keywords: copper sulfate, lettuce, seed germination, sodium nitroprusside

Abbreviations: Allometric Coefficient (AC); Mean Period of Ultimate Germination (MPUG); Seed Germination Percentage (SGP); Seed Germination Rate (SGR); Seed Vigor Index (SVI); Seedling Fresh Weight (SFW); Sodium nitroprusside (SNP)

\section{Introduction}

Copper is a micronutrient element and is the requirement for all higher plants (Berglund et al., 2000; Pätsikkä et al., 2002). It has many metabolic functions in plants and it is toxic when its concentration exceeded the minimum level in soil (Berglund et al., 2000). Copper in large quantities enters into the environment in several ways, including sewage sludge, mining, smelting, industrial activities and the extensive use of pesticides (Alaoui-Sossé $e t$ al., 2004). The highest concentration of copper is a permanent contaminant for the environment (Sheldon and Menzies, 2005). Its toxicity varies upon the type of plant and its critical concentration. For most of the plant species, the critical level of copper toxicity in the leaves is more than 20- $30 \mu \mathrm{g} / \mathrm{dw}$ (Chaignon and Hinsinger, 2003; AlaouiSossé et al., 2004).
Nitric oxide can induce a variety of activities such as regulatory, signalling and protection roles in plant cells (Beligni and Lamattina, 2001; Zhang et al., 2006) and it is a neutral lipophilic gas molecule and a reactive nitrogen species (Beligni and Lamattina, 2001). The nitric oxide chemistry refers to the interaction effect of the three redox type e.g. $\mathrm{NO}, \mathrm{NO}^{+}$and $\mathrm{NO}^{-}$. $\mathrm{NO}^{-}$is highly susceptible to oxidation and reduction (Graziano and Lamattina, 2005). Nitric oxide is produced by the enzymatic and nonenzymatic process in plants (Floryszak-Wieczorek et al., 2006). Sodium nitroprusside is a compound containing nitric oxide and its solution is sensitive to light. High temperature and oxygen can accelerate its degradation (Floryszak-Wieczorek et al., 2006).

The plants performances depend on the environmental condition and their response to stress is complex (Shams et al., 2016a; Shams et al., 2016b). Nitric oxide production could be find in various parts of plants under stress 
168

conditions. Its protective or toxicity role in plants depends upon its concentration, transmission and performance. It stimulates seed germination and cell division and enhances chlorophyll content by reacting with reactive oxygen species (Beligni and Lamattina, 2001).

The current scientific literature demonstrates that nitric oxide usage is one-way to ameliorate the plant's tolerance upon stress conditions. Therefore, the purposes of this study were to evaluate the effects of $\mathrm{NO}$ on seed germination percentage, seed germination rate, mean period of ultimate germination, seed vigor index, seedling fresh weight and allometric coefficient of lettuce seeds that subjected to copper stress.

\section{Materials and Methods}

\section{Plant material and experiment design}

To evaluate the effect of copper and nitric oxide on the seed germination and seedling development of lettuce, a factorial experiment in a completely randomized design was carried out in the Agriculture Faculty of Atatürk University in 2015. Lettuce (Lactuca sativa L. var. longifolia 'Yedikule') was used as plant material.

\section{Nitric Oxide treatments}

One percent sodium hypochlorite was used for seed disinfection about two minutes, and then seeds were washed with distilled water immediately. Seeds were soaked in different SNP (sodium nitroprusside) solutions (0, 50, 100, $200,250$ and $300 \mu \mathrm{M})$ for 24 hours in a germinator with a temperature of $23 \pm 2{ }^{\circ} \mathrm{C}$. Treated seeds were dried on the papers under room temperature. Fifty disinfected seeds treated with $\mathrm{NO}$ were germinated in 2 folds of Whatman No. 1 filter paper (sterilized) which were placed in Petri dishes (15 cm diameter). Each dish was moistened with 10 $\mathrm{ml}$ of distilled water or one of the $\mathrm{CuSO}_{4}$ solutions of 0,50 , $100,200,250$ and $300 \mu \mathrm{M}$.

\section{Investigated parameters}

Germinated seeds were counted daily. A 2-mm radicle was considered as seed germination and evaluation ended when the number of germinated seeds did not differ in two consecutive counts. The length of radicle and plumule was measured at the end of the germination counting day. SGP, SGR, MPUG, SVI, SFW and AC were calculated according the Table 1 (Ranal and Santana, 2006; Rezaei et al., 2008; Biradar et al., 2010).

\section{Statistical analysis}

Data analysis was performed by SPSS15 software and mean comparisons were done by Duncan's Multiple Range Test at a $5 \%$ significance level.

\section{Results and Discussion}

Seed Germination Percentage (SGP), Seed Germination Rate (SGR), Mean Period of Ultimate Germination (MPUG)

The statistical results showed that the copper concentrations had a significant effect on SGP, SGR and MPUG at $\mathrm{P}<0.05$. The high concentration of copper increased the MPUG (Fig. 1) and it can be due to its toxicity effect. Higher value of MPUG is not a good parameter for farming because by increasing the mean period of seed germination, seedling will be weak. Copper treatment ( $200 \mu \mathrm{M}$ of copper sulfate) decreased SGP $30 \%$ in comparison to the untreated one (Fig. 2). Decreasing in SGP and increasing in MPUG by copper are related to the drastic effect of heavy metals in germination of seeds to the decrease of the activity of $\alpha$ and $\beta$ amylases, which compromises respiration, making prevention of the growth of the embryonic axis and the radicle. In addition, the phytotoxic effect of copper elevates a disturbance in the cell development and differentiation, gives rise to abnormal seedlings and reduces the percentage of normal seedlings in germination (Liu et al., 2016; Pires et al., 2016).

In addition, inhibition of seed germinating could be related to reduction in osmotic potential of the germination medium, particularly in the attendance of a high concentration of $\mathrm{Cu}$ (Ahsan et al., 2007), and it causes water absorption by grain rather difficult. In this regard, our results confirm to those of Siddiqui et al. (2009) on pea and Kuriakose and Prasad (2008) on sorghum seeds. In contrary to our results Wierzbicka and Obidzińska (1998) reported that higher metal concentration could not affect SGR and SGP, they stated that seed coats of different species were not permeable to heavy metals. The following imbibition, in 25

Table 1. Definition and formula related to the variables related to seed germination used in this research

\begin{tabular}{|c|c|c|c|}
\hline & Variable & Formula & References \\
\hline SGP & Germination percentage & $\mathrm{GP}=\frac{\mathrm{N}}{\mathrm{N} 1} \times 100$ & (Rezaei et al., 2008) \\
\hline SGR & Germination rate & $=\sum \frac{\mathrm{Ni}}{\mathrm{Di}}$ & (Ranal and Santana, 2006) \\
\hline MPUG & Mean Period of Ultimate Germination & MPIIG $_{1}=\frac{\sum_{\mathrm{i}=1}^{\mathrm{d}} \mathrm{NiDi}}{\mathrm{UG}}$ & (Ranal and Santana, 2006) \\
\hline SVI & Seed vigor index & $\mathrm{SVI}=\mathrm{UG} \times \operatorname{Mcan}(\mathrm{RL}+\mathrm{PL})$ & (Birader et al., 2010) \\
\hline $\mathrm{AC}$ & Allometric Coefficient & $A C=\frac{R L}{P L}$ & (Ranal and Santana, 2006) \\
\hline
\end{tabular}

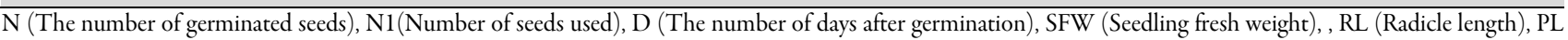
(Plumule length), UG (Ultimate germination) 
plant species under lead $(\mathrm{Pb})$ monitored that seeds avoid the over-accumulation of a pollutant in the germinating by seed coat impermeability character, so they conclude that nonsignificance of heavy metals effect on seed germination could be due to seed coat impermeability character (Kalai et al., 2014). However, our results revealed that high concentration of copper decreased SGR and SGP value. It means that response to heavy metals varies upon different species or genotypes.

The different doses of SNP did not affect the investigated parameters in seeds treated with water (without copper sulfate) (Figs. 1, 2 and 3). However, the application of SNP reversed the damages caused by copper, in this regard the simultaneous application of SNP $(200 \mu \mathrm{M})$ and copper $(100 \mu \mathrm{M})$ had highest impact on the SGR and SGP in comparing the seeds that treated by $100 \mu \mathrm{M}$ of copper sulfate without SNP (Figs. 2 and 3). Simultaneous application of SNP $(200 \mu \mathrm{M})$ and copper $(100 \mu \mathrm{M})$ also decreased MPUG value in comparing the seeds that treated by $100 \mu \mathrm{M}$ of copper sulfate without SNP (Fig 1.). Our results are contrary to those of Kopyra and Gwóźdź (2003) who reported that nitric oxide only had a stimulating effect on germination of lupine seeds under normal conditions. In the other hand, our results reflect to the findings of $\mathrm{Hu}$ et al. (2007) and Kopyra and Gwoźdź (2003) who reported the role of nitric oxide on increasing the SGP of wheat and lupine under copper and salt stress, respectively. Our results reflect to the those of Pires et al. (2016) who showed the effect of nitric oxide on sesame seeds germination under cadmium stress.

The results of this study revealed that the usage of SNP as a NO donor improved seed germination, probably due to its adjustment capacity or abolition of reactive oxygen species, decreasing the oxidative stress and ameliorating germination slightly. It is clear that the role of SNP is effective in increase of seed germination, but it is not impressive before the copper treatment.

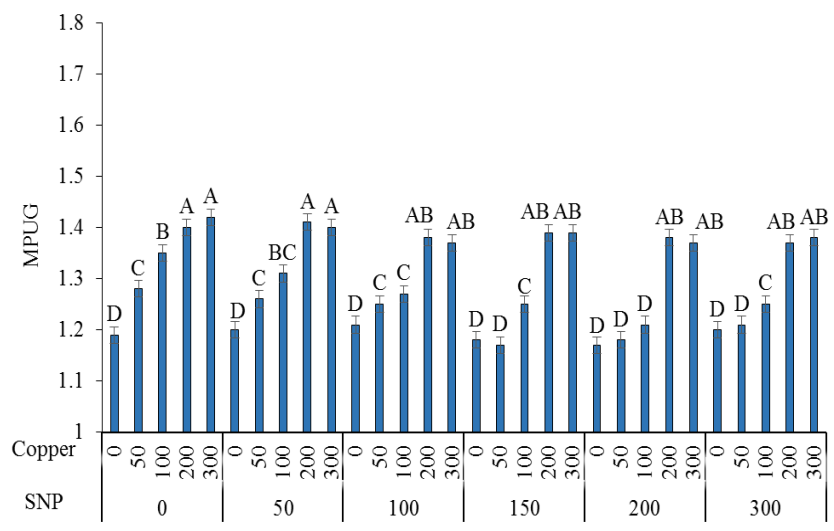

Fig. 1. The effect of SNP $(0,50,100,150,200$ and $300 \mu \mathrm{M}$ of sodium nitroprusside) and Copper (0, 50, 100, 200 and 300 $\mu \mathrm{M}$ of copper sulfate) levels on mean period of ultimate germination (MPUG). Data followed by a different letter were significantly different $(\mathrm{P} \leq 0.05)$ according to the Duncan Multiple Range Test. Vertical bars represent the standard deviation

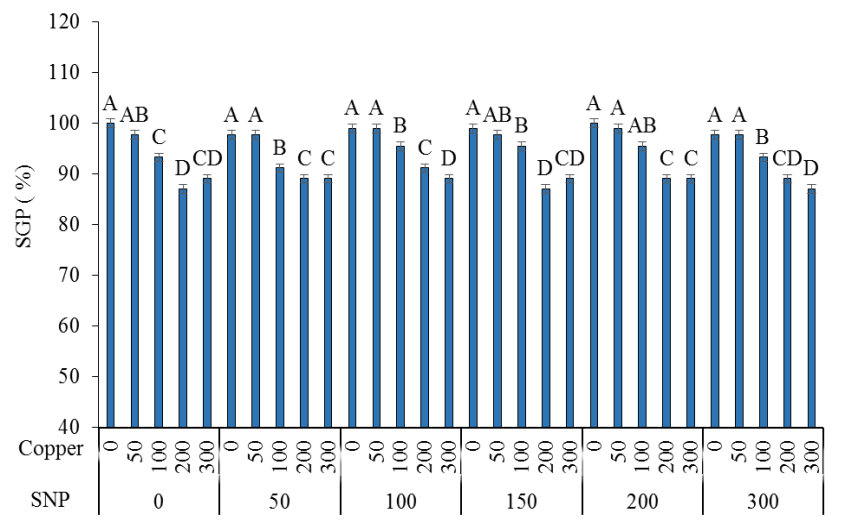

Fig. 2. The effect of SNP $(0,50,100,150,200$ and $300 \mu \mathrm{M}$ of sodium nitroprusside) and Copper (0, 50, 100, 200 and 300 $\mu \mathrm{M}$ of copper sulfate) levels on seed germination percentage (SGP). Data followed by a different letter were significantly different $(\mathrm{P} \leq 0.05)$ according to the Duncan Multiple Range Test. Vertical bars represent the standard deviation

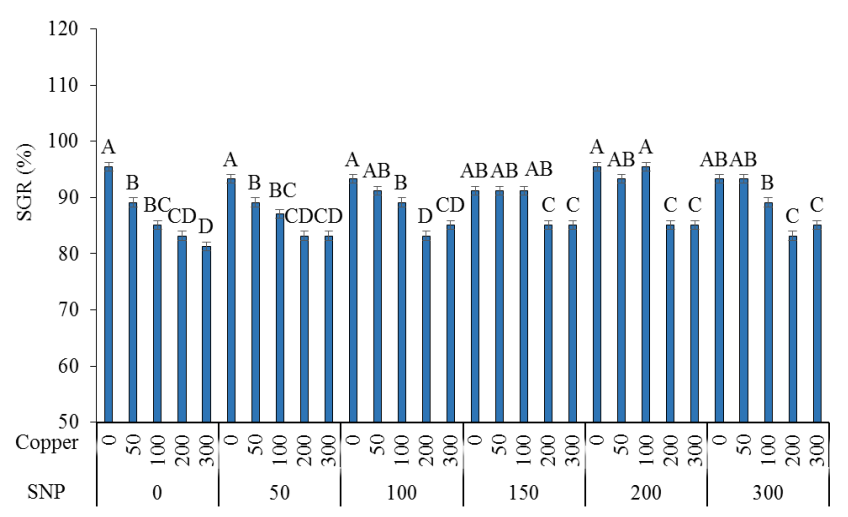

Fig. 3. The effect of SNP $(0,50,100,150,200$ and $300 \mu \mathrm{M}$ of sodium nitroprusside) and Copper (0, 50, 100, 200 and 300 $\mu \mathrm{M}$ of copper sulfate) levels on seed germination rate (SGR). Data followed by a different letter were significantly different $(\mathrm{P} \leq 0.05)$ according to the Duncan Multiple Range Test. Vertical bars represent the standard deviation

\section{Seed vigor index (SVI)}

As shown in Fig. 4, the results of this study monitored that copper had a significant effect on SVI. The high concentration of copper decreased SVI in comparison to the untreated one, but the low concentration of copper (50 $\mu \mathrm{M})$ had a positive impact on the SVI (Fig. 4). Copper (50 $\mu \mathrm{M}$ ) increased the SVI 7\% in comparison to the untreated one. Decreasing in SVI value donated the radicle and plumule length, and SGP declined by increasing in the copper concentration. Nitric oxide ( $150 \mu \mathrm{M}$ of SNP) had a positive effect on the SVI and increased it $11 \%$ in comparison to the untreated one (Fig. 4).

High copper levels decreased SVI compared to the control, but the simultaneous application of copper (100 $\mu \mathrm{M})$ and nitric oxide $(150 \mu \mathrm{M})$ increased the SVI $19 \%$ in comparison to the plants treated by $100 \mu \mathrm{M}$ of copper (Fig. 4). It means nitric oxide can reduce toxicity of copper. 
As shown in the Table 1, SVI equal is calculated by multiply of ultimate germination in the sum of radicle and plumule length. So decreasing in the SVI is resulting from reduction in the radicle and plumule length. As we know, the smallest mechanic resistant point of germinated seed is radicle and it is the first region to be in contact with the solution, being one of the main entryways of toxic metals. Radicle is the first organ that suffers from toxicity damages under presence of heavy metals in the germinating medium. It is the first organ to suffer injuries due to heavy metals, and the other organs are harmed after the transportation of these metals.

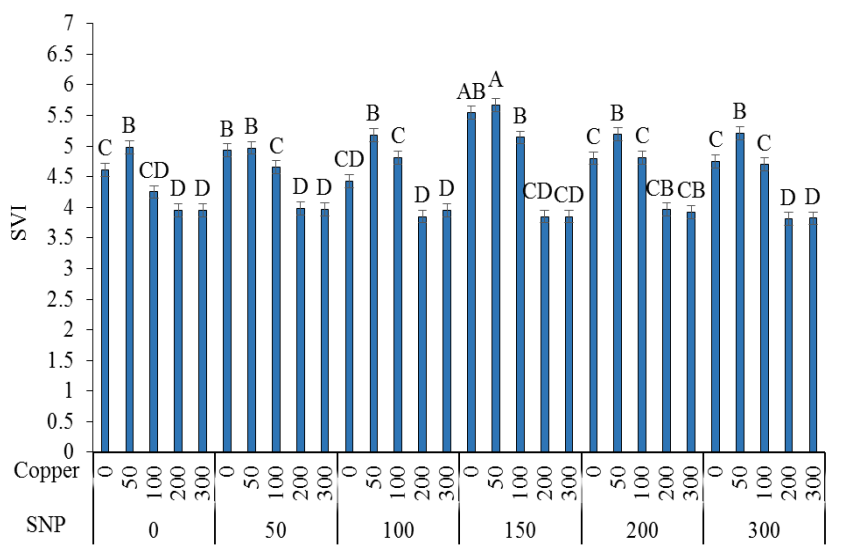

Fig. 4. The effect of SNP $(0,50,100,150,200$ and $300 \mu \mathrm{M}$ of sodium nitroprusside) and Copper (0, 50, 100, 200 and 300 $\mu \mathrm{M}$ of copper sulfate) levels on seed vigor index (SVI). Data followed by a different letter were significantly different $(\mathrm{P} \leq$ 0.05 ) according to the Duncan Multiple Range Test. Vertical bars represent the standard deviation

A significant reduction in SVI was seen when the seeds were treated with a high copper concentration in comparison to the seeds that treated with water (Fig. 4). However, the treatment of SNP alleviates the negative effect of copper toxicity, our findings confirm to those of Kopyra and Gwóźdź (2003). They found that SNP decreased the adverse effect of lead, cadmium, sodium chloride and ethylene on root growth.

The increasing in SVI by low concentration of copper $(50 \mu \mathrm{M})$ could be due to copper activation role in $\alpha$-amylase pathway production. In this regard, some studies on barley (Kalai et al., 2014), rice (He et al., 2008) and sorghum (Kuriakose and Prasad, 2008) described that heavy metals can affect the a-amylase production in seed germination stage.

\section{Seedling fresh weight (SFW)}

The results of this study revealed that copper and nitric oxide had a significant effect on the fresh weight of lettuce seedling. By increasing copper concentration, fresh weight of lettuce seedling was decreased (Fig. 5). Copper treatment $(100 \mu \mathrm{M})$ decreased SFW 7\% in comparison to the untreated one, but simultaneous application of copper (100 $\mu \mathrm{M})$ and nitric oxide $(150 \mu \mathrm{M})$ increased it $12 \%$ in comparison to the plants that treated by $100 \mu \mathrm{M}$ of copper (Fig. 5). Our findings confirm other researchers reports in which showed the adverse effect of copper on fresh and dry weight of root and stem of corn (Chaffai et al., 2005) and garden cress (Raeisi et al., 2009). Different treatments of nitric oxide had a positive effect on SFW. Nitric oxide treatment (150, 200 and $300 \mu \mathrm{M}$ of SNP) had a highest effect in comparison to the plants treated by $0 \mu \mathrm{M}$ of nitric oxide (Fig. 5).

The negative effect of copper on SFW (Fig. 5) could be related to the harmful effects of copper on plant physiological processes (Yruela, 2005). Copper toxicity also can decrease the root hair number and cell proliferation (ElTayeb et al., 2006). El-Tayeb et al. (2006) revealed that root growth of sunflower decreased and apical dominance disappeared due to root meristem cell death in higher copper stress; subsequently to maintain the survival of plants and absorb water and nutrients, the secondary root number increased, the similarity of that we found in lettuce.

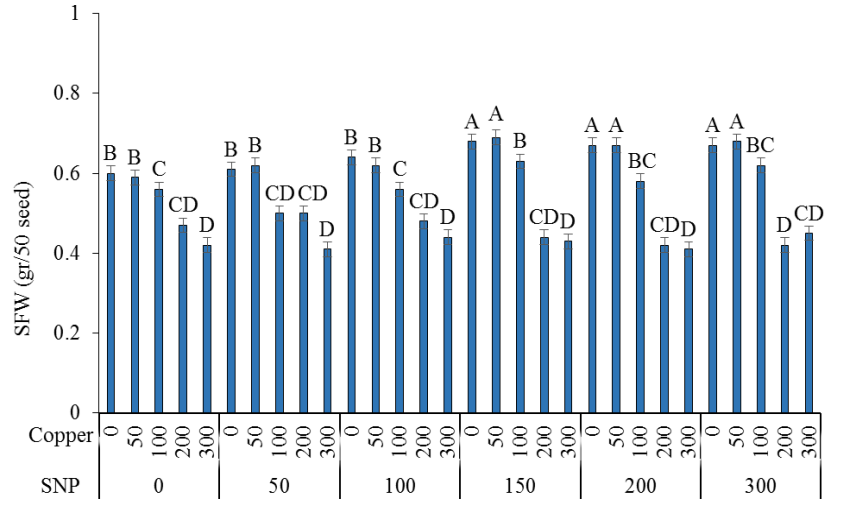

Fig. 5. The effect of SNP $(0,50,100,150,200$ and $300 \mu \mathrm{M}$ of sodium nitroprusside) and Copper (0, 50, 100, 200 and 300 $\mu \mathrm{M}$ of copper sulfate) levels on seedling fresh weight (SFW). Data followed by a different letter were significantly different $(\mathrm{P} \leq 0.05)$ according to the Duncan Multiple Range Test. Vertical bars represent the standard deviation

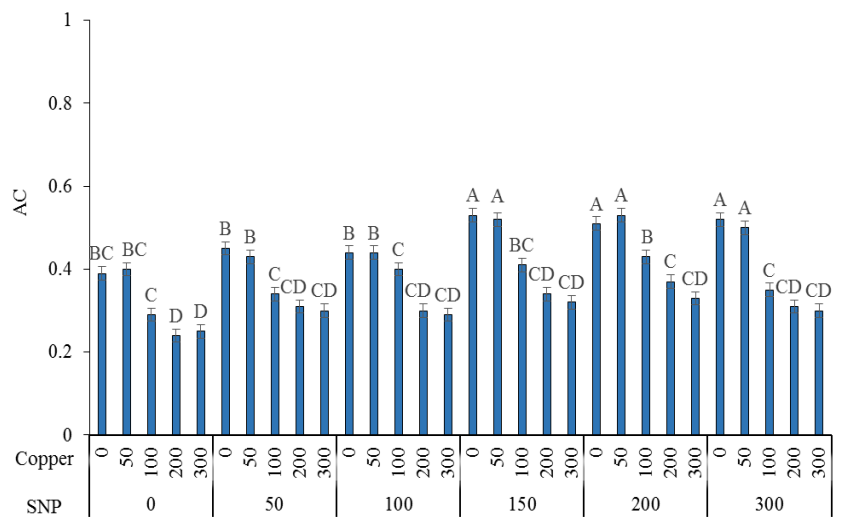

Fig. 6. The effect of SNP $(0,50,100,150,200$ and $300 \mu \mathrm{M}$ of sodium nitroprusside) and Copper (0, 50, 100, 200 and 300 $\mu \mathrm{M}$ of copper sulfate) levels on allometric coefficient (AC). Data followed by a different letter were significantly different $(\mathrm{P} \leq 0.05)$ according to the Duncan Multiple Range Test. Vertical bars represent the standard deviation 


\section{Allometric coefficient (Radicle length/Plumule length)}

Heavy metals could reduce biological activity of plants (County, 2006) and could decrease plant growth by accumulation in plants root region (Pandey and Sharma, 2002). Heavy metals also could cause a decline in nutrient elements absorbing such as nitrogen and phosphor (Pandey and Sharma, 2002). Inaba and Takenaka (2005) showed that low concentrations of the synthetic chelator's ethylenediamine tetra-acetic acid (EDTA) and diethylenetriamine penta-acetic acid (DTPA) reduced the toxicity and bioavailability of copper on lettuce sprouts.

The results of this study monitored that the copper and nitric oxide had a significant effect on the $\mathrm{AC}$ value. The high concentration of copper decreased AC (Fig. 6). Copper $(300 \mu \mathrm{M})$ had the highest negative effect on the AC and decreased it 39\% compared to control. The decreasing in $\mathrm{AC}$ value means that radicle growth was lower than the plumule growth, also it means that roots are more sensitive to copper stress than the leaves. However, the simultaneous treatment of nitric oxide $(200 \mu \mathrm{M})$ and copper $(200 \mu \mathrm{M})$ increased it to $35 \%$ in comparison to the treated plants by $200 \mu \mathrm{M} \mathrm{CuSO}_{4}$ (Fig. 6).

Nitric oxide $(150 \mu \mathrm{M})$ treatment increased AC $16 \%$ in comparison to the untreated one (Fig. 6). Increasing in AC value by $150 \mu \mathrm{M}$ SNP means that nitric oxide has a positive impact on plumule growth compared to radicle, because $\mathrm{AC}$ is resulting from plumule length / radicle length.

Decreasing in $\mathrm{AC}$ by high concentration of copper could be due to its toxicity on radicle and plumule. High concentration of copper can produce reactive oxygen species (ROS) within plant cells, ROS cause oxidative damage and membrane lipid oxidation, thus resulting retard in growth and plant development (Posmyk et al., 2009). ROS can reduce radicle and plumule cell division and also its high concentration can disrupt the pathway of a-amylase and bamylase production (Kalai et al., 2014). The copper toxicity was reduced by nitric oxide treatment, it could be due to nitric oxide role in adjusting the copper oxidative damages (Saxena and Shekhawat, 2013). Nitric oxide could also depreciate the generation of hydrogen peroxide $\left(\mathrm{H}_{2} \mathrm{O}_{2}\right)$ and diminish heavy metal toxicity by raising anti- oxidative capability (Wang and Yang, 2005) or by adjusting hormonal equilibrium ( $\mathrm{He}$ et al., 2012). So, it can be concluded that nitric oxide could mitigate the adverse effect of copper on lettuce seedlings.

\section{Conclusions}

Copper toxicity can adversely affect lettuce germinating seed and seedlings, but nitric oxide application could decrease negative effect of copper toxicity. Nitric oxide just can ameliorate seed germination and seedlings at low concentration of copper in lettuce. Nitric oxide had not a significant effect on seed germination of lettuce under nonstress condition.

\section{Acknowledgements}

The authors acknowledge Ataturk University for generous financial support.

\section{References}

Ahsan N, Lee D-G, Lee S-H, Kang KY, LeeJJ, Kim PJ, Yoon H-S, Kim J-S, Lee B-H (2007). Excess copper induced physiological and proteomic changes in germinating rice seeds. Chemosphere 67:1182-1193.

Alaoui-Sossé B, Genet P, Vinit-Dunand F, Toussaint M-L, Epron D, Badot P-M (2004). Effect of copper on growth in cucumber plants (Cucumis sativus) and its relationships with carbohydrate accumulation and changes in ion contents. Plant Science 166:1213-1218.

Beligni M, Lamattina L (2001). Nitric oxide in plants: the history is just beginning. Plant Cell Environment 24:267-278.

Berglund A, Quartacci M, Liljenberg C (2000). Changes in plasmamembrane lipid composition: a strategy for acclimation to copper stress. Biochemical Society Transactions 28:905-907.

Biradar KS, Salimath P, Ravikumar R (2010). Genetic variability for seedling vigour, yield and yield Components in local germplasm collections of greengram (Vigna radiata (L.) wilczek). Karnataka Journal of Agricultural Sciences 20(3):608-609.

Chaffai R, Tekitek A, El FerjaniE(2005). Comparative effects of copper and cadmium on growth and lipid content in maize seedlings (Zea mays L.). Pakistan Journal of Biological Sciences 8:649-655

Chaignon V, Hinsinger P (2003). A biotest for evaluating copper bioavailability to plants in a contaminated soil. Journal of Environmental Quality 32:824833.

County N (2006). Influence of cadmium on growth of root vegetable and accumulation of cadmium in the edible root. International Journal of Applied Science and Engineering 3:243-252.

El-Tayeb M, El-Enany A, Ahmed N (2006) Salicylic acid-induced adaptive response to copper stress in sunflower (Helianthus annuus L). Plant Growth Regulation 50:191-199.

Floryszak-Wieczorek J, Milczarek G, Arasimowicz M, Ciszewski A (2006). Do nitric oxide donors mimic endogenous NO-related response in plants. Planta 224:1363-1372.

Graziano M, Lamattina L (2005). Nitric oxide and iron in plants: an emerging and converging story. Trends in Plant Science 10:4-8.

HeH-Y,HeL-F, Gu M-H,LiX-F(2012)Nitric oxide improves aluminum tolerance by regulating hormonal equilibrium in the root apices of rye and wheat. PlantScience 183:123-130.

He J-y, Ren Y-f, Cheng Z, Jiang D-a (2008). Effects of cadmium stress on seed germination, seedling growth and seed amylase activities in rice (Oryzasativa). RiceScience 15:319-325.

Hu K-D, Hu L-Y,Li Y-H,ZhangF-Q,ZhangH (2007). Protective roles of nitric oxide on germination and antioxidant metabolism in wheat seeds under copper stress. Plant Growth Regulation 53:173-183.

Inaba S, Takenaka C (2005). Effects of dissolved organic matter on toxicity and bioavailability of copper for lettuce sprouts. Environment International 31:603-608.

Kalai T, Khamassi K, Teixeira Da Silva JA, Gouia H, Bettaieb Ben-Kaab L (2014). Cadmium and copper stress affect seedling growth and enzymatic activities in germinating barley seeds. Archives of Agronomy and Soil Science 60:765-783. 
172

Kopyra M, Gwóźdź EA (2003). Nitric oxide stimulates seed germination and counteracts the inhibitory effect of heavy metals and salinity on root growth of Lupinus luteus. Plant Physiology and Biochemistry 41:10111017.

Kuriakose SV, Prasad M (2008). Cadmium stress affects seed germination and seedling growth in Sorghum bicolor (L.) Moench by changing the activities of hydrolyzing enzymes. Plant Growth Regulation 54:143-156.

Liu R, Zhang H, Lal R (2016). Effects of stabilized nanoparticles of copper, zinc, manganese, and iron oxides in low concentrations on lettuce (Lactuca sativa) seed germination: nanotoxicants or nanonutrients? Water, Air, \&Soil Pollution 227:1-14.

Pandey N, Sharma CP (2002). Effect of heavy metals Co $2+, \mathrm{Ni} 2+$ and Cd 2+ on growth and metabolism of cabbage. PlantScience 163:753-758.

Pätsikkä E, Kairavuo M, Šeršen F, Aro E-M, Tyysţärvi E (2002). Excess copper predisposes photosystem II to photoinhibition in vivo by outcompeting iron and causing decrease in leaf chlorophyll. Plant Physiology 129:1359-1367.

Pires RMdO, Souza GAd, Cardoso AÁ, Dias DCFdS (2016). Action of nitric oxide in sesame seeds (Sesamum indicum $\mathrm{L}$.) submitted to stress by cadmium. Journal of Seed Science 38:22-29.

Posmyk M, Kontek R, Janas K (2009). Antioxidant enzymes activity and phenolic compounds content in red cabbage seedlings exposed to copper stress. Ecotoxicology and Environmental Safety 72:596-602.

Raeisi M, Asrar Z, Pourseyedi S (2009). Interaction of sodium nitroprusside and copper on some growth and physiologic parameters of garden cress (Lipidum sativum L.). Iranian Journal of Plant Biology 1: 55-76.

Ranal MA, Santana DGd (2006). How and why to measure the germination process? Brazilian Journal of Botany 29:1-11.

Rezaei F, Yarnia M, Mirshekari B (2008) Allopathic effects of Chenopodium album, Amaranthus retrofelexus and Cinodon dactylon on germination and growth of rapeseed. Agroecology Journal 4:41-55.
Saxena I, Shekhawat GS (2013). Nitric oxide (NO) in alleviation of heavy metal induced phytotoxicity and its role in protein nitration. Nitric Oxide 32:13-20

Shams M, Ramezani M, Esfahan SZ, Esfahan EZ, Dursun A, Yildirim E (2016a). Effects of climatic factors on the quantity of essential oil and dry matter yield of coriander (Coriandrum sativum L.). Indian Journal of Science and Technology 9(6).

Shams M, Yildirim E, Ekinci M, Turan M, Dursun A, Parlakova F, Kul R (2016b). Exogenously applied gycine betaine regulates some chemical characteristics and antioxidative defence systems in lettuce under salt stress. Horticulture Environment and Biotechnology 57:225-231.

Sheldon A, Menzies N (2005). The effect of copper toxicity on the growth and root morphology of Rhodes grass (Chloris gayana Knuth.) in resin buffered solution culture. Plant and Soil 278:341-349.

Siddiqui S, Meghvansi MK, Wani MA, Jabee F (2009). Evaluating cadmium toxicity in the root meristem of Pisum sativum L. Acta Physiologiae Plantarum 31:531-536.

Wang Y-S, Yang Z-M (2005) Nitric oxide reduces aluminum toxicity by preventing oxidative stress in the roots of Cassia tora L. Plant and Cell Physiology46:1915-1923.

Wierzbicka M, Obidzińska J (1998). The effect of lead on seed imbibition and germination in different plant species. Plant Science 137:155-171.

Yruela I (2005). Copper in plants. Brazilian Journal of Plant Physiology 17:145-156.

Zhang Y, Wang L, Liu Y,Zhang Q, Wei Q,Zhang W (2006). Nitric oxide enhances salt tolerance in maize seedlings through increasing activities of proton-pump and $\mathrm{Na}+/ \mathrm{H}+$ antiport in the tonoplast. Planta 224:545555. 